\title{
Особливості компенсаторних процесів дванадцятипалої кишки при обтураційному холестазі в поеднанні з декомпресією жовчних шляхів та ентеросорбціею
}

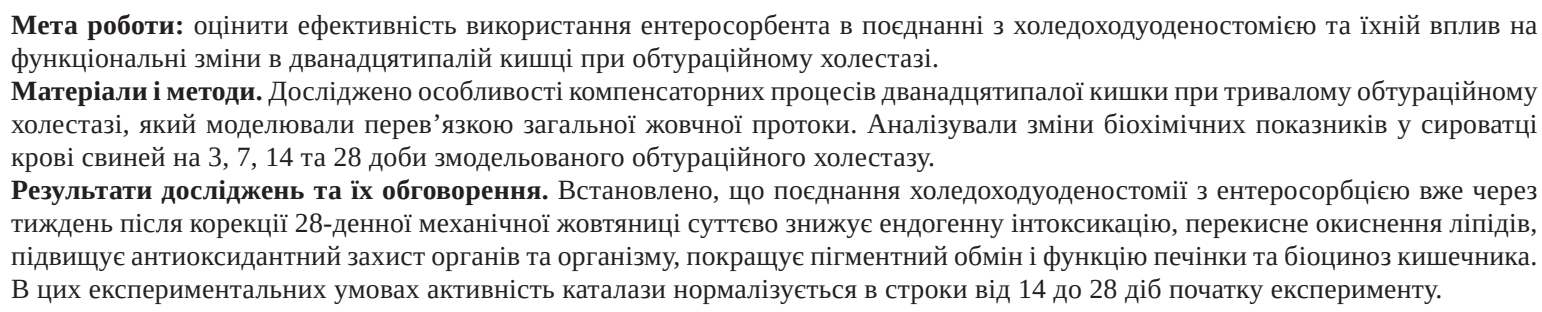

Мета роботи: оцінити ефективність використання ентеросорбента в поєднанні з холедоходуоденостомією та їхній вплив на функціональні зміни в дванадцятипалій кишці при обтураційному холестазі.

Матеріали і методи. Досліджено особливості компенсаторних процесів дванадцятипалої кишки при тривалому обтураційному холестазі, який моделювали перев’язкою загальної жовчної протоки. Аналізували зміни біохімічних показників у сироватці крові свиней на 3, 7, 14 та 28 доби змодельованого обтураційного холестазу.

Результати досліджень та їх обговорення. Встановлено, що поєднання холедоходуоденостомії з ентеросорбцією вже через тиждень після корекції 28-денної механічної жовтяниці суттєво знижує ендогенну інтоксикацію, перекисне окиснення ліпідів, підвищує антиоксидантний захист органів та організму, покращує пігментний обмін і функцію печінки та біоциноз кишечника. В цих експериментальних умовах активність каталази нормалізується в строки від 14 до 28 діб початку експерименту.

Ключові слова: обтураційний холестаз; дванадцятипала кишка; ендогенна інтоксикація; сорбент.

Постановка проблеми і аналіз останніх досліджень та публікацій. Обтураційний холестаз супроводжується недостатнім або відсутнім надходженням жовчі в дванадцятипалу кишку. При цьому стані порушується травна функція органу, всмоктування жирів, оскільки ліпаза шлункового соку при відсутності жовчі стає малоефективною. При цьому жири не емульгуються і їхній контакт із ліполітичними ферментами ускладнений. При ахолії страждає також всмоктування жирних кислот, холестерину та жиророзчинних вітамінів. Внаслідок цього розвивається стеаторея - надлишковий вміст жиру в калових масах. В цих умовах при дефекації виводиться до 70-80 \% жиру [5]. Стінки кишечника вистелені жировими скупченнями, що гальмує дію протеолітичних ферментів. Відсутність жовчі в дванадцятипалій кишці сприяє зміні лужного середовища на кисле, що суттєво знижує функцію травлення білків та вуглеводів. Посилене виведення із кишечника жиророзчинних вітамінів супроводжується гіповітамінозом та порушенням згортання крові внаслідок дефіциту вітаміну К. При ахолії та гіпокаліємії знижується бактерицидна дія жовчі, що призводить до посилення ендогенної інтоксикації. Також при обтураційному холестазі послаблюється перистальтика кишечника, погіршується травлення та наростає інтоксикація. Відомо, що тривала біліарна гіпертензія спричиняє підвищення тиску в системі ворітної вени [1], що порушує кровообіг в дванадцятипалій кишці. Підвищення тиску в венозній системі супроводжується сповільненням кровотоку, розширенням артеріальних та венозних частин судинного русла [7].
Мета роботи: оцінити ефективність використання ентеросорбента в поєднанні з холедоходуоденостомією та їхній вплив на функціональні зміни в дванадцятипалій кишці при обтураційному холестазі.

Матеріали і методи. Оскільки в перші дні після декомпресії жовчних шляхів наростає ендогенна інтоксикація, яка впливає на відновлення функціональних та структурних змін дванадцятипалої кишки, тому з метою зменшення інтоксикації та покращення відновних процесів ми дослідили 23 експериментальні тварини (статевозрілі свині самці в'єтнамської породи) з 28-денним обтураційним холестазом, яким за 7 днів до декомпресії жовчовивідних шляхів давали разом 3 кормом ентеросорбент карболайн в розрахунку 0,7 г/кг маси тварини. Так, через 3 доби після декомпресії жовчних шляхів з використання ентеросорбента було вивчено судинне русло вищевказаного органа трьох свиней, після 7 діб - у 3-х тварин, після 14 діб - у 4-х свиней, після 28 діб - у 4-х тварин. Рівень ендогенної інтоксикації визначали за концентрацією молекул середньої маси. Останні визначали за методикою Н. І. Габрієляна i В. В. Кравця (2007) [11]. Для цього сироватку крові обробляли $10 \%$ розчином трихлороцтової кислоти у співвідношенні 1,0:0,5. Осад відділяли шляхом 30-хвилинного центрифугування при обертах 3000 за хв. Супернатант розводили дистильованою водою у співвідношенні 1:10 і спектрофотометрували при довжині світлових хвиль 280 нм і 254 нм, визначаючи відповідно концентрацію середніх молекул $\left(\mathrm{CMП}_{1}\right.$ та СМП $)$. У сироватці крові визначали концентрацію загального, прямого і непрямого бі- 
лірубіну за методом Yendrassik i Gleghorn. Одним із найбільш поширених у клінічних і експериментальних умовах тестів $€$ визначання у сироватці крові активності аланін- і аспартамінотрансфераз (відповідно АлАТ і АсАТ). Дані речовин $є$ компонентами цитоплазми гепатоцитів. Внаслідок зростання проникливості цитоплазматичних мембран при активних гепатитах вони потрапляють у сироватку крові. Концентрація амінотрансфераз пропорційна ступеню руйнування гепатоцитів і активності патологічного процесу [12]. Активність АлАТ і АсАТ у сироватці крові визначали за допомогою наборів реактивів "Bio-Test” фірми "Chema Diagnostica" (м. Монсано, Італія). Механічна жовтяниця також супроводжується вираженим внутрішньопечінковим холестазом: одним з найбільш ранніх критеріїв цього процесу є зростання активності у сироватці крові лужної фосфатази - ЛФ. Діагностичне значення має при цьому також гамма-глутамінтранспептидаза. Визначення активності ферментів ЛФ та гамма-глутамінтранспептидази виконували за допомогою набору реактивів ПраТ “Реагент" (м. Дніпро, Україна). Відомо, що в патогенезі уражень органів при механічній жовтяниці провідне місце займає перекисне окиснення ліпідів, а також антиоксидантна система захисту [3, 6]. Вміст продуктів перекисного окиснення ліпідів - малонового діальдегіду (МДА) та дієнових кон'югатів (ДК) визначали за методом Z. Placer. Активність каталази сироватки крові визначали за методом М. А. Корольова, відновлений глутатіон за G. L. Elman. Отриманий цифровий матеріал був оброблений методом варіаційної статистики з використанням критерію Стьюдента і в інших викладках - за допомогою U-критерію МаннаУїтні. Різницю між середніми величинами вважали достовірною при вірогідності альтернативної гіпотези не менше як $95 \%$.
Результати досліджень та їх обговорення. Через 3 доби після декомпресії жовчних шляхів свині були малоактивними, хоча жовтяничність склер та слизових оболонок були значно меншими порівняно з тваринами контрольної серії спостереження. Тиск у загальній жовчній протоці при цьому становив $(1,40 \pm 0,11)$ кПа, у ворітній вені - $(1,35 \pm 0,06)$ кПа, а об'ємна швидкість органного кровообігу в дванадцятипалій кишці становила $(39,6 \pm 1,2)$ мл/100 хв. Результати досліджень свідчать, що поєднане використання ентеросорбції та декомпресії жовчних шляхів для корекції механічної жовтяниці найбільш оптимально впливало на біохімічні показники [13]. При цьому було виявлено, що в даних умовах експерименту через 3 доби від його початку суттєво знижувався рівень загального білірубіну (табл. 1). Однак цей показник статистично достовірно відрізнявся від такої ж контрольної величини, хоча був нижчим порівняно з групою спостережень, де при механічній жовтяниці виконували лише холедоходуоденостомія. Через 7 діб від початку даного досліду концентрація загального білірубіну в сироватці крові не відрізнялася від такої у контрольних спостереженнях. Підвищеним залишався рівень прямого білірубіну. Концентрація останнього у сироватці крові досягала 2,7 мкмоль/л і перевищувала аналогічний контрольний показник в 1,28 раза. При цьому рівень непрямого білірубіну в сироватці крові не відрізнявся від такого ж у контрольних спостереженнях. Через 14 діб від початку експерименту концентрація загального білірубіну в сироватці крові не перевищувала аналогічної величини в контрольних спостереженнях. Слід сказати, що ці показники були стабільними через 28 , 60 та 180 діб від початку даного досліду [2]. Одержані дані показали, що поєднання ентеросорбції

Таблиця 1. Рівні білірубінів та активності аланінтрансферази, аспартатамінотрансферази, лужної фосфатази та гамма-глутамінтранспептидази у сироватці крові свиней з 28-денною механічною жовтяницею,

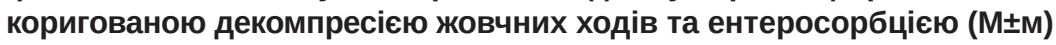

\begin{tabular}{||l|c|c|c|c||}
\hline \multirow{2}{*}{\multicolumn{1}{|c|}{ Показник }} & \multicolumn{4}{c||}{ Групи тварин } \\
\cline { 2 - 5 } & 3 доби & 7 діб & 14 діб & 28 діб \\
\hline Білірубін загальний, мкмоль/л & $93,20 \pm 2,52$ & $74,20 \pm 0,51$ & $20,50 \pm 0,54$ & $15,70 \pm 0,42$ \\
\hline АлАт, мккат/л & $0,4180 \pm 0,015^{* * *}$ & $0,3960 \pm 0,016 * *$ & $0,3210 \pm 0,012 *$ & $0,2290 \pm 0,015$ \\
\hline АсАт, мккат/л & $0,0580 \pm 0,006^{*}$ & $0,0510 \pm 0,006$ & $0,0406 \pm 0,007$ & $0,0360 \pm 0,009$ \\
\hline ЛФ, мккат/л & $1,220 \pm 0,018$ & $1,180 \pm 0,021$ & $1,162 \pm 0,024$ & $1,154 \pm 0,030$ \\
\hline $\begin{array}{l}\text { Гамма-глутамінтранспептидаза, } \\
\text { мкмоль/л }\end{array}$ & $0,390 \pm 0,008 * * *$ & $0,356 \pm 0,007 * * *$ & $0,310 \pm 0,006 * *$ & $0,225 \pm 0,012$ \\
\hline \hline
\end{tabular}

Примітка. Зірочкою позначено величини, які статистично достовірно відрізняються від контрольних. 
3 декомпресією жовчних шляхів більш позитивно впливало на покращення рівня загального, прямого та непрямого білірубіну, ніж окремо застосування холедоходуоденостомії або ентеросорбції для корекції механічної жовтяниці. Активність аланінамінотрансферази в цих експериментальних умовах також знижувалася. Особливо вираженим покращення активності даної трансамінази спостерігали через 7 діб від початку досліду.

Слід також вказати, що активність аланінамінотрансферази залишалася ще підвищеною і через 14 діб даного експерименту.

У більш віддаленні строк цього досліду вона нормалізувалася.

У цих експериментальних умовах активність аспартатамінотрансферази була істотно підвищеною лише через 3 доби від початку даного досліду. В більш пізніші строки експерименту вона суттєво не відрізнялася від контрольних показників. Активність лужної фосфатази вже через 3 доби від початку даного досліду істотно не відрізнялася від контрольних показників. Активність лужної фосфатази вже через 3 доби від початку даного досліду істотно не відрізнялася від контрольних показників. В більш пізніші строки цього експерименту активність лужної фосфатази була стабільною і не відрізнялася від аналогічної величини в інтактних свиней [9]. В цих експериментальних умовах активність гамма-глутамілтранспептидази знижувалася вже з перших днів експерименту. Нормалізацію цього показника встановлено через 28 діб від початку досліду. Слід вказати, що поєднане застосування ентеросорбції з холедоходуоденостомією краще впливало на покращення описаних біохімічних показників, ніж окреме використання декомпресії жовчних шляхів при механічній жовтяниці або лише ентеросорбції. Поєднане застосування декомпресії жовчних шляхів та ентеросорбції для корекції 28-денної механічної жовтяниці істотно знижувало рівні середньомолекулярних пептидів, що свідчило про зменшення ендогенної інтоксикації. Через 14 діб даного експерименту концентрація СМП 1 та СМП 2 у сироватці крові дослідних свиней не відрізнялася від контрольних величин. В дальші строки даного експерименту (14, 28 діб) ці показники залишалися стабільними [5]. Концентрації дієнових кон'югатів та малонового діальдегіду в даних експериментальних умовах зменшувалися порівняно із некоригованою механічною жовтяницею. Так, через 3 доби від початку даного досліду рівень дієнових кон'югатів знижувався $3(0,615 \pm 0,021)$ до $(0,503 \pm 0,012)$ мкмоль/л, а концентрація малонового діальдегіду з $(0,588 \pm 0,024)$ до $(0,460 \pm 0,011)$ нмоль/л, тобто, відповідно, на $18,2 \%$ та 12,7 \%. Це свідчило про зниження інтенсивності реакції перекисного окиснення ліпідів [10]. У змодельованих умовах експерименту спостерігали зростання концентрації відновленного глутадіону в крові та збільшення активності каталази. Так, рівень відновленого глутатіону на 3 день експерименту зростав із $(2,75 \pm 0,12)$ до $(4,10 \pm 0,12)$ нмоль/л, тобто майже на $49,0 \%$. В цих експериментальних умовах активність каталази збільшувалася з $(8,0 \pm 0,36)$ до $(12,16 \pm 0,36)$ мккат/л, тобто на 52,0 \%. Слід вказати, що на 14 добу даного експерименту концентрація дієнових кон'югатів, малонового діальдегіду та відновленого глутатіону нормалізувалася. Активність каталази в ці строки досліду залишалася ще суттєво пониженою. Нормалізація даного показника спостерігалася на 28 добу даного експерименту. В більш віддалені строки спостережень досліджувані показники суттєво не відрізнялися від аналогічних контрольних величин (табл. 2).

Таблиця 2. Рівні середньомолекулярних пептидів, малонового діальдегіду, дієнових кон'югатів, відновленого глутатіону та активність каталази в сироватці крові свиней 3 28-денним обтураційним холестазом, корегованим декомпресією жовчних ходів та ентеросорбцією (М士м)

\begin{tabular}{||c|c|c|c|c||}
\hline \multirow{2}{*}{\multicolumn{1}{|c|}{ Показник }} & \multicolumn{3}{|c||}{ Групи тварин } \\
\cline { 2 - 5 } & 3 доби & 7 діб & 14 діб & 28 діб \\
\hline СМП, ум. од. & $24,05 \pm 9,6^{*}$ & $206,9 \pm 7,2^{*}$ & $182,4 \pm 9,3$ & $179,20 \pm 9,0$ \\
\hline СМП , ум. од. & $203,8 \pm 8,4^{*}$ & $180,4 \pm 11,4$ & $170,5 \pm 8,4$ & $171,9 \pm 8,2$ \\
\hline Дієнові кон'югати, мкмоль/л & $0,503 \pm 0,012^{*}$ & $0,486 \pm 0,011$ & $0,475 \pm 0,015$ & $0,468 \pm 0,018$ \\
\hline Малоновий діальдегід, нмоль/л & $0,460 \pm 0,011^{*}$ & $0,446 \pm 0,012^{*}$ & $0,390 \pm 0,018$ & $0,392 \pm 0,019$ \\
\hline Відновлений глутатіон, нмоль/л & $4,10 \pm 0,12^{* * *}$ & $4,60 \pm 0,15^{* *}$ & $5,30 \pm 0,18$ & $5,62 \pm 0,30$ \\
\hline Каталаза, мккат/л & $12,16 \pm 0,36 * * *$ & $13,40 \pm 0,39 * *$ & $15,10 \pm 0,42 *$ & $16,98 \pm 0,51$ \\
\hline \hline
\end{tabular}

Примітки. ${ }^{*}-\mathrm{p}<0,05 ; * *-\mathrm{p}<0,01 ; * * *-\mathrm{p}<0,001$ порівняно з контролем. В решті випадків $-\mathrm{p}>0,05$. 
Висновок. Отже, результати проведених досліджень свідчать, що поєднання холедоходуоденостомії з ентеросорбцією вже через тиждень при корекції 28-денної механічної жовтяниці суттєво знижує ендогенну інтоксикацію, перекисне окиснення ліпідів, підвищує антиоксидантний захист органів та організму, покращує пігментний обмін і функцію печінки та біоциноз кишечника. В цих експериментальних умовах активність каталази нормалізується в строки від 14 до 28 діб початку експерименту.
Перспективи подальших досліджень. Дані біохімічні показники сироватки крові можуть бути використані в післяопераційному лікуванні пацієнтів з обтураційним холестазом, що в перспективі зменшить відновний період після даної патології. Врахування перелічених результатів при виконанні даної роботи зумовить чіткіші патогенетичні підходи до діагностики, корекції та профілактики структурно-функціональних змін у дванадцятипалій кишці при обтураційному холестазі.

\section{СПИСОК ЛІТЕРАТУРИ}

1. Эндогенная интоксикация при механической желтухе и возможности ее патогенетической коррекции / А. Н. Беляев, С. А. Беляев, С. В. Костин [и др.] // Эксперим. и клинич. гастроэнтерология. - 2018. - № 157 (9). - С. 101-106.

2. Пилипчук В. І. Варіанти операційних втручань на жовчовивідних протоках при хронічному панкреатиті з ознаками біліарної гіпертензії / В. І. Пилипчук // Шпитальна хірургія. Журнал імені Л. Я. Ковальчука. - 2016. - № 2. - С. 27-31. 3. Sobazstiano P. Pathophysiology of chronic damage / P. Sobazstiano, F. di Molat // Acute and chronic pancreatitis. Turin: Editioni Minerva modica, 2013. - P. 63-69.

4. Пат. UA78273, МПК G 09B23/28(2006/01) Спосіб моделювання механічної жовтяниці / Гнатюк М. C. - № U201211327; заявл.01.10.2012; опубл.11.03.2013, Бюл. № 5.

5. Возможности индуцирования репарации тканей при механической желтухе неопухолевого происхождения / А. П. Власов, П. П. Зайцев, В. А. Болотских [и др.] // Хирургия. Журнал им. Н. И. Пирогова. - 2018. - № 12. - С. 57-64.

6. Методика морфологічних досліджень / М. М. Багрій, В. А. Діброва, О. Г. Попадинець, М. І. Грищук. - Вінниця : Нова-Книга, 2008. - 318 с.

7. Гнатюк М. С. Особливості структурної перебудови судин гемомікроциркуляторного русла дванадцятипалої кишки при обтураційному холестазі / М. С. Гнатюк, Л. В. Татарчук, С. О. Грабчак // Здобутки клініч. і експерим. медицини. - 2016. - № 4. - С. 36-39.

\section{REFERENCES}

1. Belyayev, A.N., Belyayev, S.A., Kostin, S.V., Tyurina, N.A., \& Boyarkin, Ye.V. (2018). Endogennaya intoksikatsiya pri mekhanicheskoy zheltukhe i vozmozhnosti yeye patogeneticheskoy korrektsii [Endogenous intoxication in mechanical joundice and the possibility of its pathogenetic correction]. Eksperimentalnaya i klinicheskaya gastroenterologiya - Experimental and Clinical Gastroenterology, 157 (9), 101-106. DOI: 10.31146/1682-8658ecg157-9-101-106 [in Russian].

2. Pylypchuk, V.I. (2016). Varianty operatsiinykh vtruchan na zhovchovyvidnykh protokakh pry khronichnomu pankreatyti z oznakamy biliarnoi hipertenzii [Possible surgeries on bile ducts in cases of chronic pancreatitis with signs of biliary hypertension]. Shpytalna khirurhiia. Zhurnal imeni L.Ya. Kovalchuka Hospital Surgery. Journal named by L.Ya. Kovalchuk, 2, 27-31. DOI: https://doi.org/10.11603/2414-4533.2016.2.6406 [in Ukrainian]. 3. Sobazstiano, P., \& di Molat, F. (2013). Pathophysiology of chronic damage. Acute and Chronic Pancreatitis. Turin: Editioni Minerva modica.

8. Горальський Л. П. Структурна перебудова гемомікроциркуляторного русла дванадцятипалої кишки при перебігу ї̈ виразки в умовах дії хімічного фактора / Л. П. Горальський, Т. І. Гаргула, М. С. Гнатюк // Здобутки клініч. і експерим. медицини. - 2012. - № 2 (17). - С. 39-42.

9. Дзюбановський О. І. Вплив декомпресії жовчовивідних шляхів на динаміку процесів жовчоутворення і жовчовиділення після експериментального холестазу різної тривалості / О. І. Дзюбановський, А. А. Гудима // Клінічна хірургія. 2017. - № 10. - С. 66-69.

10. Динамика показателей гомеостаза у больных с механической желтухой неопухолевой этиологии / М. Д. Кашаева, А. В. Прошин, А. В. Голушко, К. В. Гаврилова // Медико-фармацевтический журнал “Пульс”. - 2020. - Т. 22, № 2. - С. 42-48. 11. Кравець В. В. Морфологічні зміни у тонкій кишці під впливом різних ендогенних та екзогенних чинників (огляд літератури) / В. В. Кравець // Вісник Сумського держ. ун-ту. Сер. “Медицина”. - 2008. - № 1. - С. 5-16.

12. Шифф Ю. Р. Болезни печени по Шиффу. Вирусные гепатиты и холестатические заболевания: руководство / Ю. Р.Шифф, М. Ф. Соррел, У. С. Мэддрей ; пер. с англ. под ред. В. Т. Ивашкина и др. - М. : ГЭОТАР-Медиа, 2010. - 397 с. 13. Возможности энтеросорбции и эволюция энтеросорбентов для лечения хирургического эндотоксикоза / С. И. Емельянов, Б. С. Брискин, Д. А. Демидов, Т. И. Демидова // Экперим. и клинич. гастроэнтерология. - 2010. - № 11. - С. 84-89.

4. Patent UA78273, MPK G 09B23/28(2006/01). Sposib modeliuvannia mekhanichnoi zhovtianytsi [A method for modeling mechanical jaundice]. M.S. Hnatiuk - No U201211327; zaiavl. 01.10.2012; opubl.11.03.2013, Bull. No. 5 [in Ukrainian].

5. Vlasov, A.P., Zaitsev, P.P., Bolotskikh, V.A., Vlasova, T.I., Davydkin, V.I., Sheyranov, N.S., \& Okunev, N.A. (2018). Vozmozhnosti indutsirovaniya reparatsii tkaney pri mekhanicheskoy zheltukhe neopukholevogo proiskhozhdeniya [Possibilities of tissue repair induction during mechanical jaundice of non-tumor genesis]. Khirurgiya. Zhurnal im. N.I. Pirogova - Surgery. Journal named after N.I. Pyrogov, 12, 57-64. DOI: https://doi. org/10.17116/hirurgia201812157 [in Russian].

6. Bahrii, M.M., Dibrova, V.A., Popadynets, O.H., \& Hrychuk, M.I. (2008). Metodyka morfolohichnykh doslidzhen [Methods of morphological studies]. Vinnytsia: Nova-Knyha [in Ukrainian]. 7. Hnatiuk, M.S., Tatarchuk, L.V., \& Hrabchak, S.O. (2016). Osoblyvosti strukturnoi perebudovy sudyn hemomikrotsyrkulyatornoho rusla dvanadtsiatypaloi kyshky pry obturatsiinomu kholestazi 
[Peculiarities of structural reconstruction of microhemocirculatory bed vessels of duodenum at the obturative cholestasis]. Zdobutky klinichnoi i eksperymentalnoi medytsyny - Achievements of Clinical and Experimental Medicine, 4, 36-40. DOI: https://doi. org/10.11603/1811-2471.2016.v0.i4.7073 [in Ukrainian].

8. Horalskyi, L.P., Harhula, T.I., \& Hnatiuk, M.S. (2012). Strukturna perebudova hemomikrotsyrkuliatornoho rusla dvanadtsiatypaloi kyshky pry perebihu yii vyrazky v umovakh dii khimichnoho faktora [Structural restructuring of the hemomicrocirculatory tract of the duodenum during the course of its ulcer under conditions of chemical factor]. Zdobutky klinichnoi i eksperymentalnoi medytsyny - Achievements of Clinical and Experimental Medicine, 2 (17), 39-42 [in Ukrainian].

9. Dzyubanovskyi, O.I., \& Hudyma, A.A. (2017). Vplyv dekompresii zhovchovyvidnykh shliakhiv na dynamiku protsesiv zhovchoutvorennia i zhovchovydilennia pislia eksperymentalnoho kholestazu riznoi tryvalosti [Impact of the biliary ducts decompression on dynamics of bile production and bile excretion after experimental cholestasis of different duration]. Klinichna khirurhiia - Clinical Surgery, 10, 66-69. DOI: https://doi. org/10.26779/2522-1396.2017.10.66 [in Ukrainian].

10. Kashaeva, M.D., Proshin, A.V., Golushko, A.V., \& Gavrilova, K.V. (2020). Dinamika pokazateley gomeostaza u bol'nykh s mekhanicheskoy zheltukhoy neopukholevoy etiologii [Dy- namics of indicators of homeostasis in patients with mechanical jaundy nontumorous ethiology]. Mediko-farmatsevticheskiy zhurnal "Puls" - Medical \& Pharmaceutical Journal "Pulse", 22, 2, 42-48. DOI: http://dx.doi.org/10.26787/nydha-2686-6838-2020-22-2-42-48 [in Russian].

11. Kravets, V.V. (2008). Morfolohichni zminy u tonkii kyshtsi pid vplyvom riznykh endohennykh ta ekzohennykh chynnykiv (ohliad literatury) [Morphological changes in the small intestine under the influence of various endogenous and exogenous factors (literature review)]. Visnyk Sumskoho derzh. un-tu. Ser. "Medytsyna" - Bulletin of the Sumy State University. Ser. "Medicine”, 1, 5-16 [in Ukrainian].

12. Shiff, Yu.R., Sorrel, M.F., \& Meddrey, U.S. (2010). Bolezni pecheni po Shiffu. Virusnyye gepatity i kholestaticheskiye zabolevaniya: rukovodstvo [Diseases baked according to Schiff. Viral hepatitis and cholestatic diseases: a guide]. Ivashkin, V.T. (Ed.). Moscow: GEOTAR-Media [in Russian].

13. Yemelyanov, S.I., Briskin, B.S., Demidov, D.A., \& Demidova, T.I. (2010). Vozmozhnosti yenterosorbtsii i yevolyutsiya yenterosorbentov dlya lecheniya khirurgicheskogo yendotoksikoza [Possibilities of enterosorption and evolution of enterosorbents for the treatment of surgical endotoxicosis]. Ekperim. i klinich. gastroenterologiya - Experimental and Clinical Gastroenterology, 11, 84-89 [in Russian].

Отримано 04.02.21

Електронна адреса для листування: grabchak_so@tdmu.edu.ua

S. O. GRABCHAK, A. D. BEDENYUK

I. Horbachevsky Ternopil National Medical University

\section{FEATURES OF COMPENSATORY PROCESSES OF THE DUODENUM IN OBTURATIVE CHOLESTASUS IN COMBINATION WITH DECOMPRESSION OF THE BILIARY PATHWAYS AND ENTEROSORPTION}

The aim of the work: to evaluate the effectiveness of the use of enterosbent in combination with cold stochaestostomy and their impact on functional changes in the duodenum in obstructive cholestasis.

Materials and Methods. The peculiarities of the compensatory processes of the duodenum in long-term obstructive cholestasis, which was modeled by ligation of the common bile duct, were studied. Changes in biochemical parameters in the serum of pigs at 3, 7, 14 and 28 days of simulated obstructive cholestasis were analyzed.

Results and Discussion. Studies have shown that the combination of choledochoduodenostomy with enterosorption in a week after correction of 28-day mechanical jaundice significantly reduces endogenous intoxication, lipid peroxidation, increases antioxidant protection of organs and the body, improves pigment metabolism and liver function. Under these experimental conditions, catalase activity is normalized within 14 to 28 days of the start of the experiment.

Key words: obstructive cholestasis; duodenum; endogenous intoxication; sorbent. 
С. О. ГРАБЧАК, А. Д. БЕДЕНЮК

Тернопольский национальный медицинский университет имени И. Я. Горбачевского МОз Украины

\section{ОСОБЕННОСТИ КОМПЕНСАТОРНЫХ ПРОЦЕССОВ ДВЕНАДЦАТИПЕРСТНОЙ КИШКИ ПРИ ОБТУРАЦИОННОМ ХОЛЕСТАЗЕ В СОЧЕТАНИИ С ДЕКОМПРЕССИЕЙ ЖЕЛЧНЫХ ПУТЕЙ И ЭНТЕРОСОРБЦИЕЙ}

Цель работы: оценить эффективность использования энтеросбента в сочетании с холедоходуоденостомиею и их влияние на функциональные изменения в двенадцатиперстной кишке при обтурационном холестазе.

Материалы и методы. Исследованы особенности компенсаторных процессов двенадцатиперстной кишки при длительном обтурационном холестазе, который моделировали перевязкой общего желчного протока. Анализировали изменения биохимических показателей в сыворотке крови свиней на 3, 7, 14 и 28 сутки смоделированного обтурационного холестаза.

Результаты исследований и их обсуждение. Проведенными исследованиями установлено, что сочетание холедоходуоденостомии с энтеросорбцией уже через неделю после коррекции 28-дневной механической желтухи существенно снижает эндогенную интоксикацию, перекисное окисление липидов, повышает антиоксидантную защиту органов и организма, улучшает пигментный обмен и функцию печени и биоциноз кишечника. В этих экспериментальных условиях активность каталазы нормализуется в сроки от 14 до 28 суток начала эксперимента.

Ключевые слова: обтурационный холестаз; двенадцатиперстная кишка; эндогенная интоксикация; сорбент. 